\title{
Natural Resource Management for the World's Highest Park: Community Attitudes on Sustainability for Central Karakoram National Park, Pakistan
}

\author{
Talib Hussain ${ }^{1, *}$, Jaffar Abbas ${ }^{2}$, Benqian Li ${ }^{1, *}$, Jaffar Aman ${ }^{3}$ and Sajjad Ali ${ }^{1}$ \\ 1 School of Media and Design, Shanghai Jiao Tong University, 800, Dongchuan Rd. Minhang-District, \\ Shanghai 200240, China; sajjad@sjtu.edu.cn \\ 2 Glorious Sun School of Business and Management, Donghua University, 1882, West Yan'an Road, \\ Shanghai 200051,China; 411019@mail.dhu.edu.cn or abbas.jaffar@hotmail.com \\ 3 School of Sociology and Political Science, Shanghai University, 99 Shangda Road, Baoshan District, \\ Shanghai 200444, China; uthebest@i.shu.edu.cn \\ * Correspondence: talibhussian@sjtu.edu.cn (T.H.); libenqian@sjtu.edu.cn (B.L.) \\ Academic Editor: Tan Yigitcanlar \\ Received: 28 January 2017; Accepted: 31 May 2017; Published: 7 June 2017
}

\begin{abstract}
The management of natural resources has become a crucial agenda item at the community level of every country, due to the importance of a community's direct involvement in the stewardship of these resources. The sustainable management of natural resources is not easy without the involvement of the community. To know the attitudes of residents in the communities in close proximity to Central Karakoram National Park (CKNP) towards natural resource sustainable management policy, a study of CKNP in northern Pakistan was conducted. This is the first community study for this park. It is difficult to overstate the economic and geographic importance of this national resource to the Pakistani people at local and national levels, as well as at the international level. This is the world's highest public park; as a natural resource it is not only important to the local community, it also has great relevance internationally. The study attempted to gauge the attitudes of the local community towards the sustainable management practices of CKNP. The results of this study showed generally positive attitudes towards the park. The majority of respondents revealed that the park's primary appeal is its geographic location. Households were afraid that pollution in the park will gradually destroy the park's natural resources. For sustainable management of the CKNP, community members expressed willingness to contribute to the betterment of park through volunteerism. Community members praised the government's supportive actions, including budgetary support and public-awareness campaigns. As such, the positive attitude of the community towards the CKNP also revealed new insights for the community-centered sustainable management of natural resources in developing countries. This study also provides a research gap for future work relating to the sustainable management of community-based natural resources to consider more factors beside the factors used in this study.
\end{abstract}

Keywords: community sustainability; natural resource sustainable management; community impacts; community attitude; Central Karakoram National Park

\section{Introduction}

Natural resource-rich communities are uniquely situated at the intersection of human society and the environment. Due to the need for deep involvement of communities in natural resource management, theory and practice relating to the interactions of human society and natural resources have become widespread. Across the globe, the literature related to community involvement in 
natural resource management is abundant. However, specific findings and disclosures relating to community and natural resource management across disciplinary lineages and development contexts are largely limited because of the diverse perspectives and interests involved in the study of community and natural resources. To provide a stronger dimension of sustainability, community-based natural-resource sustainability offers an overarching framework for better understanding community and natural resource management relations. This study specifically focused on discovering the practices and frameworks towards community and natural resource sustainable management in a developing country [1] and is unique in that respect. To know the community attitudes and intentions towards sustainable management of natural resources, a publicly owned and internationally reputed natural resource, Central Karakoram National Park, Pakistan (CKNP) was the target for this study. This study provided insights in the interrelationships of society, natural resources, and sustainability at the community level.

\section{Central Karakoram National Park, Pakistan}

CKNP is the highest national park on Earth and the largest natural resource protection zone in Pakistan. It is located in the Gilgit-Baltistan area of northern Pakistan [2]. The park contains some of the world's highest peaks and most massive glaciers [3], and is globally famous for hiking and trekking opportunities [4].The area of this park is about 10,000 sq. km, including four well-known peaks over 8000 m: K2 (8611 m), Gasherbrum-I (8068 m), Broad Peak (8051 m), Gasherbrum-II (8035 m), as well as 60 peaks higher than $7000 \mathrm{~m}$ [5].The benefits of this park for the local communities extend to all aspects of the park, including, but not limited to: forestry, tourism, mining, cropland, wildlife, vegetation, aromatic plants, livestock, water, and local community culture [4]. However, the worldwide importance of this park has sparked interest by Pakistan's governmental and non-governmental organizations to shield and sustainably maintain the park's resources. Hence, the benefits redound not only to the local community but also to international interests relating to the conservation of the world's natural resources. In recent years, governmental and non-governmental organizations have introduced a variety of programs and policies to protect CKNP; however, conflicts due to the multiple uses of the park have led to many problems relating to the park's management [2]. This study aimed to elicit community insights relating to the sustainable management of CKNP, concerning the community's use of the park, what the local community can do for the protection local environment, and their recommendations to governmental and non-governmental organizations for improving the environmental sustainability of CKNP. This study specifically focused on the attitudes of community residents in close proximity to CKNP and concludes with their remarks for further policy development. It also assesses the probable influences that may affect the local people's perception towards their environment, with special attention paid to CKNP. The findings of this study will be useful for policymaking agencies; for government and non-government organizations; and for local bodies, for the sustainable management of CKNP.

\section{Literature Review}

\subsection{Community Involvement and Sustainable Management of Natural Resources}

The increasingly complex relations of the community and management of natural resources requires new ways of thinking in policy research. The community itself has a strong and significant relationship with and role in natural resource management. The success of sustainable plans mainly depends on how well the local communities themselves view the environment and its multifarious measures, and on how thoroughly local communities are involved in the practice of policy implementation [6]. Plans for the management of resources may fail if the communities do not adopt them properly. The multiple use-modes of these natural resources also create problems for their proper management [7]. Multiple users of natural resources often depend on these resources for their survival; therefore, they tend to rely on immediate economic benefit. Sometimes, 
the communities in conservation areas are mainly engaged in exploiting the natural resources to obtain an immediate economic benefit rather than considering the environmental effects [8], therefore their proper involvement is well known as a crucial factor in the management of resources throughout the history of natural resources management $[9,10]$.

A consistent definition of community may encourage greater consensus among researchers for understanding the relationship between communities and resource management; however, there is no reasonably consistent definition in the literature [11]. Some theorists define community as that group of people which has the same geography, such as a neighborhood, town, or city; some mention social network groups as a community, which allows for the decoupling of community from a physical locale [12]. A psychological sense of mutual belonging of a group may also shape community [12]. In the literature, community has been referred to as a variable or agent to find its relationship with natural resource management $[13,14]$.

Since 2000, a focus on motivating and convincing communities and individuals to become involved in the management of natural resources has been taken as a global manifesto by the United Nations [15]. Research on human psychology and related disciplines has reflected the growing public interest in community involvement. Community and resource management has a long history. We found in previous studies that most researchers have focused on answering such questions as why and how communities get involved in community-related projects, as well as how communities engage themselves for longer periods and with greater benefits $[16,17]$. Currently, there are also many challenges in the establishment of community involvement in the sustainable management of natural resources. There are critiques relating to how and why communities get involved in unpaid volunteer projects which may be pushed by governmental and non-governmental organizations. Community involvement also refers to the actions of communities that lead to volunteerism [18] or the actions performed by representative paid groups, for example, those who are responsible for the management of the resources and those groups who receive remuneration from the community $[19,20]$. Austin and Hasenfeld [21] concluded in their research that increased outside pressure on communities to perform voluntary work were merely designed by and for governments to drive public-based social projects, thereby somewhat contradicting the idea of "volunteerism." Owen, too, found that to push the public towards unpaid volunteer involvement tended to fail due to governments' retrenchment without attention to actual community needs [22].

Other researchers $[23,24]$ have argued that unpaid, volunteer community involvement in public-based projects may yield short-term benefits, but that these actions may also reduce the intrinsic motivation of the public to perform such actions in the near future. In communities, individuals may practice volunteerism within the community at times to get a short-term individual reward, as well as to fulfill egoistic goals [25]. Community involvement in the management of resources through community-based groups and governmental and non-governmental organizations may also help to cement the bond between the community and natural resources [26].

\subsection{Community and Sustainable Management of Natural Resources}

A country's natural resources are its essential backbone. They provide raw material for industry and serve as markers for national pride. Sustainable natural resource management refers to the management of land, water, environment, animals, and plants over an extended period of time. This discipline relates to the interactions of people and natural landscapes [27]. Regarding the relationship of community to natural resource management, Thakadu assumed three conditions: (a) local communities are better ambassadors to protect natural resources; (b) communities will preserve a resource only if its benefits surpass the costs of preservation; and (c) communities will conserve the resources that have a direct link to their economic benefit [28]. Community attitude and the conservation of natural resources have a direct relationship with each other [29].

Community-level natural resource management is referred to as the management of community-based resources by local bodies, governmental, and non-governmental organizations [30]. 
Sometimes, local communities are reluctant to contest a government's recommendations for fear of losing promised benefits on which the communities are highly dependent [31]. If communities practice sustainable management of their resources, then other people may also want to settle in that environment as their own resources become unsustainable [32]. The education, cooperation, location, and attitudes of community residents are contributing factors for better sustainable management of natural resources in a community setting [33]. Dittmar [32] stated that if communities restrict access to a natural environmental area to foot traffic, it encourages a sustainable community by decreasing mass transportation and waste in conservation areas. The administrative bodies (government or other local authorized bodies) tasked with setting goals play a vital role in sustainable resource management, because communities themselves typically are not equipped to set and implement plans on their own [34]. CKNP is a place which needs a sustainable management policy to preserve its natural resources. This is the first work to study the attitudes of local community residents towards CKNP, and it provided useful information for the sustainable management of the park.

\section{Materials and Methods}

CKNP is surrounded by all districts of Gilgit-Baltistan, Pakistan [35] (Figure 1). Households in close proximity to CKNP were selected to represent the community in the park. A total of 240 households were randomly selected through stratified probability sampling. First, the population within close proximity areas to CKNP was divided into different strata and then a simple random sample from each stratum was obtained. The stratum of population was obtained from the census department of the local government, which was based on the geographic location characteristics of the community.

For data collection and analysis, semi-structured and open-ended questionnaires were developed and found valid in pre-test results. The questionnaires were administered by the researchers themselves. To measure the demographic characteristics of the respondents, the variables of age, income level, and location were added to the questionnaire. Some questions were asked based on Likert five-point scales to know the attitudes of the respondents towards CKNP. Open-ended questions, such as 'what are community concerns about CKNP?' were used in the survey, which helped the researchers to gain an in-depth response of the community towards the park.

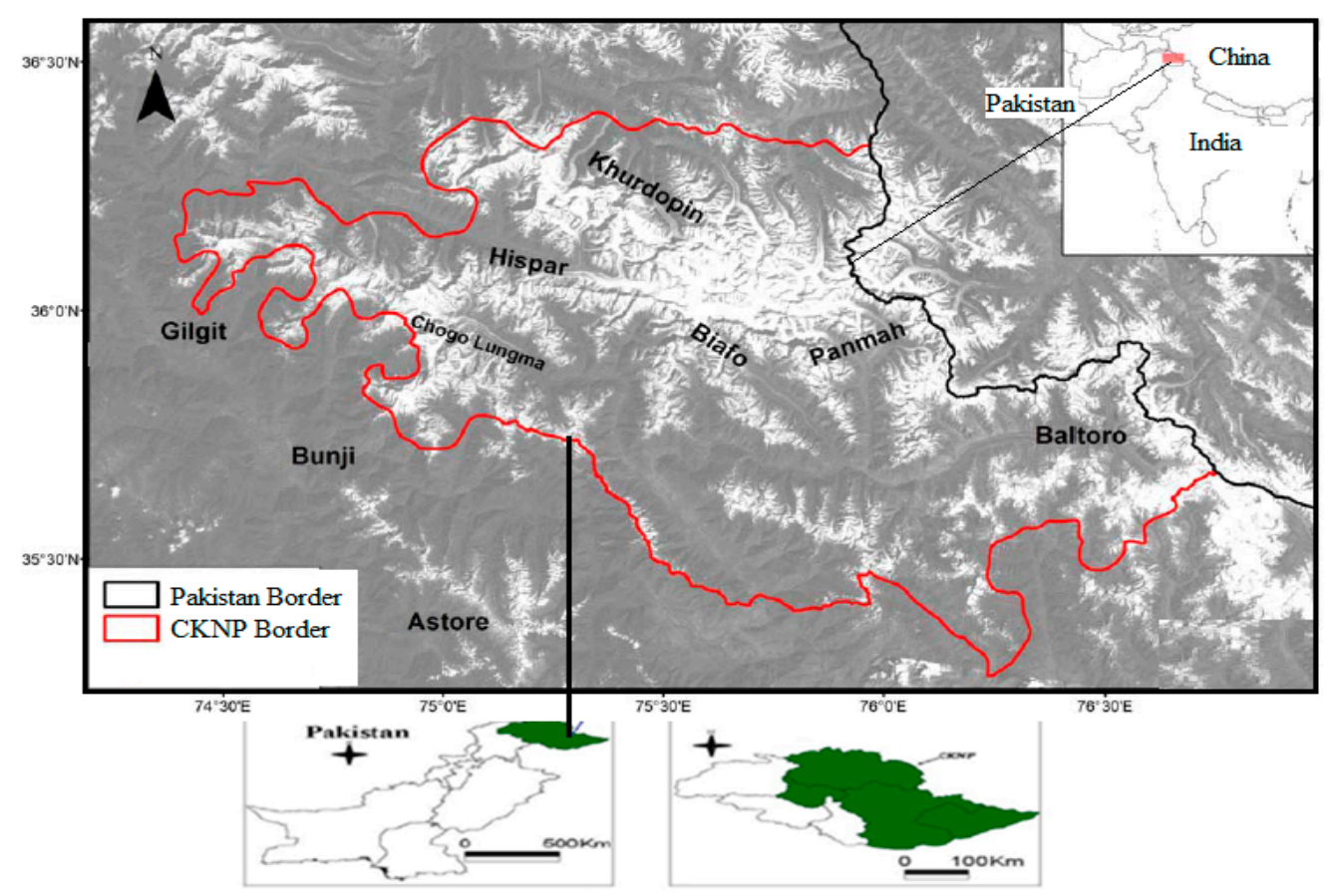

Figure 1. Geography of Central Karakoram National Park (CKNP), Pakistan [35]. 


\subsection{Model for the Study}

For this study, the variables of age, gender, location, income, and the willingness of the community to exert environmental effort were recognized as the independent variables; the attitude of community members of CKNP was identified as the dependent variable. To know whether there were significant relationships among the variables, a correlation analysis was performed. Two types of questions were used, open-ended and structured. The Spearman's correlation analysis was used for the categorical data and the Pearson correlation analysis was used for the continuous data. For the results, a $p$-value of 0.10 was considered significant. To know the attitude of the community, a statement, "I think CKNP is beneficial for local community living in proximity to this park" was asked from respondents based on Likert five-point scale; ranging from strongly agree to strongly disagree.

Table 1 shows the details of the socio demographic characteristics of households and the descriptive analysis. These characteristics were gender $(1=$ male, $2=$ female), age $(1=$ Less than 10 years, $2=10-18$ years, $3=19-29$ years, $4=30-39$ years , $5=40-49$ years, $6=50-59$ years, 7 = Above 60 years $)$, monthly household income $(1=$ Less than Rs.8000, $2=$ Rs.8001-Rs.15,000, $3=$ Rs.15,001-Rs.35,000, $4=$ Above 35,001), and location proximity to CKNP ( $1=$ Gilgit, $2=$ Skardu, $3=$ Astore, $4=$ Hunza Nager, $5=$ Diamer, $6=$ Ghizer, $7=$ Ghanchi).

Table 1. Explanation of variables.

\begin{tabular}{|c|c|c|c|c|c|}
\hline Variables & Variable Type & Category & Method of Analysis & Mean & Std. Deviation \\
\hline $\begin{array}{l}\text { Location of household } \\
\text { from CKNP }\end{array}$ & $\begin{array}{l}\text { Independent } \\
\text { Variable }\end{array}$ & $\begin{array}{l}\text { Categorical } \\
\text { Variable }\end{array}$ & $\begin{array}{c}\text { Spearman's } \\
\text { correlation analysis }\end{array}$ & 2.76 & 1.985 \\
\hline Income of household & $\begin{array}{l}\text { Independent } \\
\text { Variable }\end{array}$ & $\begin{array}{l}\text { Categorical } \\
\text { Variable }\end{array}$ & $\begin{array}{c}\text { Spearman's } \\
\text { correlation analysis }\end{array}$ & 3.93 & 1.575 \\
\hline $\begin{array}{c}\text { Willingness of } \\
\text { household towards } \\
\text { CKNP'senvironmental } \\
\text { protection }\end{array}$ & $\begin{array}{l}\text { Independent } \\
\text { Variable }\end{array}$ & $\begin{array}{l}\text { Continuous } \\
\text { Variable }\end{array}$ & $\begin{array}{l}\text { Standard Pearson's } \\
\text { correlation analysis }\end{array}$ & 3.5 & 1.369 \\
\hline
\end{tabular}

CKNP: Central Karakoram National Park.

\subsection{Research Statements}

Based on the previous literature, the following research statements (RS) were developed for this study (Figure 2).

RS1: The location of the community has a significant relationship towards the sustainable management of CKNP [32].

RS2: The nearby community of CKNP has a willing attitude to take part in their role for the sustainable management of park [18].

RS3, RS4, RS5: Age (RS3), gender (RS4), and income level (RS5) [29,36] within the community, each have a significant relationship to the sustainable management of CKNP.

RS6: The overall attitude of the community towards CKNP is positive $[33,37,38]$.

Based on research statements the details of the variable have been formatted in Figure 2. 


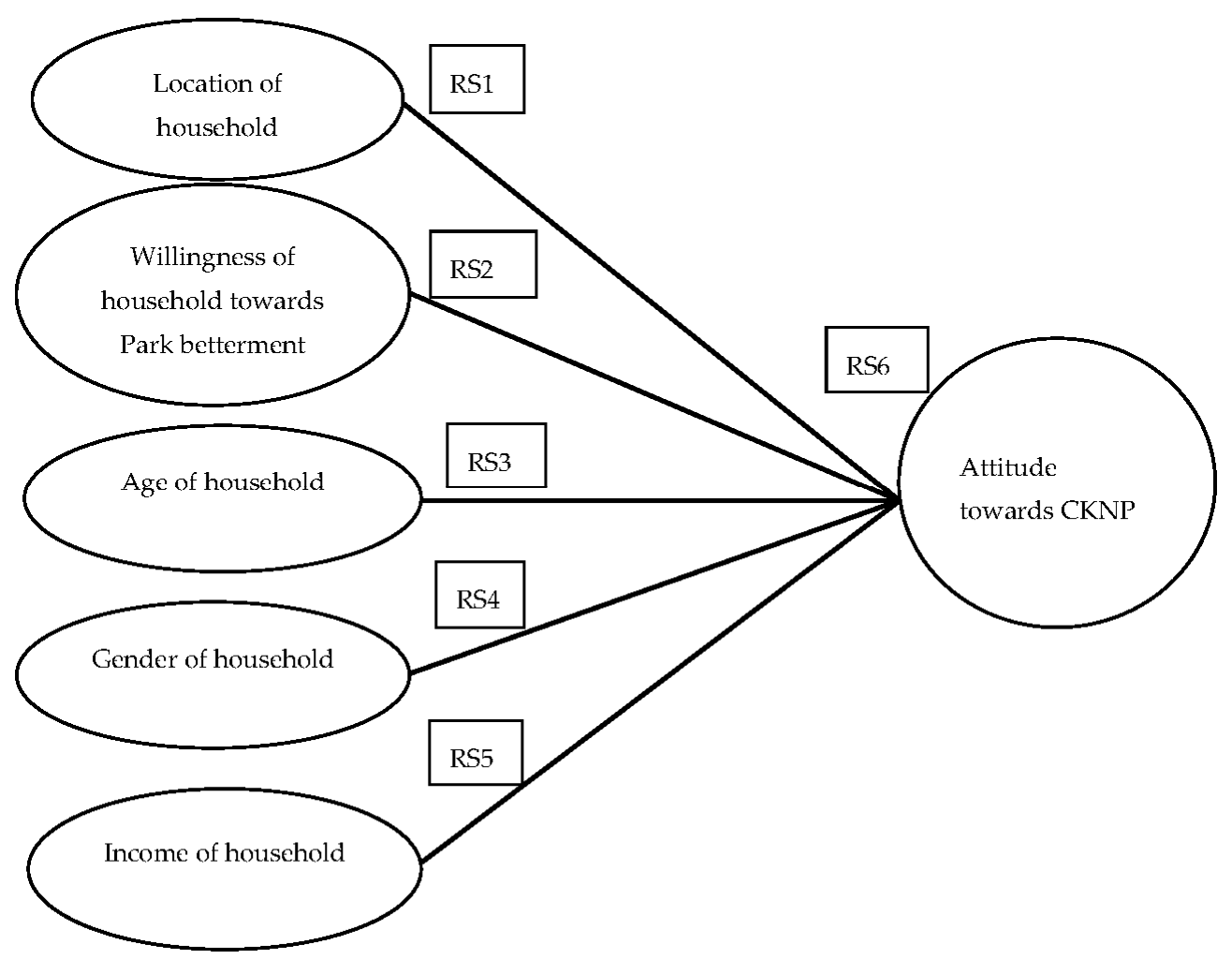

Figure 2. Variables of the study. RS: Research Statement.

\section{Results}

A total of 240 questionnaires were distributed among households within the community nearby CKNP. Of the participants, $54 \%$ were male and $46 \%$ female. Participants were between the ages of 20 and 70 years. The income level of the households ranged from a minimum US $\$ 10,000$ (PKR 100,000) to a maximum US\$20,000 (PKR 200,0000) annually.

Regarding the general attitude of the community towards CKNP, the majority (52\%) of the households indicated that the natural environment of the park is suffering from increasing pollution. Around $28 \%$ of respondents indicated that the environment of CKNP is no longer natural. Some respondents $(17 \%)$ argued that CKNP is a good resource to gain economic benefit for the community. Only $3 \%$ of respondents did not comment at all about the park.

The most important and common uses of CKNP were identified as: a source of livelihood for the community $(40 \%)$, a tourist destination $(24.8 \%)$, a water supply $(15 \%)$, and a natural environment for animals and plants (12.2\%). Some respondents $(8 \%)$ indicated that CKNP is polluted and that the benefits are therefore drastically reduced for the community.

The respondents described CKNP as facing a growing pollution challenge. Respondents identified that the major cause of the pollution and deterioration was due to waste dumping by both the local community and tourist activity. Community members (65\%) indicated that a significant cause of pollution in CKNP is the discharge of waste by the local community. Respondents also indicated that around $35 \%$ of the park's pollution has been caused by tourism activities and tourist littering.

About $58 \%$ of respondents indicated that the physical and geographical conditions of CKNP, including the location of the park, flora and fauna in the park, and the natural environment of the park influence their perception for the park. Around 36\% of respondents indicated that the presence of waste and polluted water in the park influences their perceptions towards the park. Only $6 \%$ of respondents indicated that news reports in the media about the current conditions of CKNP influence their perceptions towards the park. 
Respondents were asked to elaborate on their views regarding pollution in CKNP. Around 33.7\% of respondents indicated that the pollution in the park was destroying the natural environment of the conservation area. Around one quarter of respondents (25.3\%) indicated that the park's pollution made a strong negative impact on the local community regarding their livelihood and other matters relative to basic survival. Around $15 \%$ of respondents felt that the pollution in the park will increasingly diminish and perhaps destroy the natural water-flow rate, on which the local community depends. Nearly $26 \%$ of respondents believed that the pollution of the park may jeopardize economic activity for the local communities.

The majority of community members $(94.2 \%)$ felt that the ongoing destruction of the natural environment of CKNP is becoming a crucial issue for them, and that there is need to protect the environment of CKNP. About 35\% of respondents felt that government action is necessary for the protection of the park. Around $25 \%$ of respondents argued that there is a need to implement a budget every year for sustainable protection of the natural environment of the park. Nearly $19 \%$ of respondents indicated that instituting and implementing environmental management measures could help the sustainable management of the park. Concerning contributions towards sustainable environmental protection of the park, $15 \%$ of respondents stated that they were ready to help shoulder the financial burden for park protection, such as through government taxes, etc. Almost $6 \%$ of respondents argued that they were voluntarily ready to provide services to protect the natural conservative environment of CKNP.

\section{Variable Significance and Correlation Tests}

Table 2 presents the variables indicating community attitudes towards CKNP. The responses of the community were found to be significantly correlated $(p<0.10)$ in terms of income, age, general positive attitude towards the park, and a willingness to expend efforts towards park remediation.

Table 2. Variables affecting community attitude towards the sustainable management of CKNP.

\begin{tabular}{ccc}
\hline Variables & $\boldsymbol{R}$ & $p$ \\
\hline Location of the respondent & 0.065 & 0.396 \\
Willingness to take part in environmental effort for CKNP & 0.143 & $0.060^{*}$ \\
Age of the respondent & 0.195 & $0.076^{*}$ \\
Income level of the respondent & 0.148 & $0.066^{*}$ \\
Gender of the respondent & -0.053 & 0.490 \\
Attitude of the respondent towards CKNP & 0.650 & $0.016^{*}$ \\
\hline
\end{tabular}

${ }^{*} p<0.10$ was considered significant.

\section{Discussion, Findings, and Recommendations}

As to the research statements in this study, Table 1 suggests a willing attitude of the community (RS2) towards environmental protection of CKNP, age (RS3), and income level (RS5) of respondents, as well as the attitude of the community towards the park (RS6) were all found to correlate significantly, whereas location (RS1) and gender (RS4) characteristics of the community were found not significant.

Table 1 shows that the attitude of the local community towards sustainable management of the CKNP is significantly favorable and those households surrounding the park had a generally positive perception towards it. In the literature, positive attitude within communities towards natural resource management corresponds to better management of those resources. Bohner and Wanke made the same finding in their study, specifically noting that a community's positive attitude towards natural resource management contributes to better sustainable management of resources [37]. Likewise, Pollnac's study on Indonesia's coastal environment [38] also concluded that people's positive attitude absolutely helps to manage the community-based natural resources.

The socioeconomic level of community members also was found to correlate with attitudes about better sustainable management of CKNP. Similar findings can be found in the study conducted by Cinner and Pollnac [36], in that the socioeconomic health of community members contributed to 
positive attitudes towards natural resource management and a desire for improved management of natural resources.

The results of this study showed that community members feel that the Central Karakorum National Park is beneficial for the livelihood of the local community and that it is important to manage the park sustainably. However, respondents also indicated that due to abuse by community members and tourists, the park's natural environment is under threat. Community members feel that CKNP would benefit from immediate protective action by the government.

The general attitude of the community towards CKNP was shaped by the community members' direct and immediate experience with park. Government and media reports did not compel the community to think protectively about the park. There is a need to increase the role of the media and develop improved strategies to spread awareness within the community towards the sustainable management of the park.

This study also found that the community nearby CKNP is voluntarily ready to take an active role in the protection of the park. Although in the literature it was found that governments routinely push communities towards unpaid volunteer involvement, this typically fails when agencies cut costs without attending to community needs [18]. It is recommended that agencies do not depend chiefly on voluntary participation of the community. Unpaid and volunteer community involvement in CKNP may give some short-term benefits, but over time and without official assistance these actions may also reduce the intrinsic motivation of community members to perform such actions in the future [23,24]. However, as indicated in results of this study, community members favorably viewed increased taxation in relation to sustainability, suggesting a generally cooperative rather than dependent attitude.

Around $35 \%$ of respondents indicated that government action is necessary for the protection of the natural conservative environment of the park. The same attitudes were also found by Driscoll et al. [26], where government participation towards resource management and protection was encouraged.

In this study, the community indicated that around 35\% of the pollution of the CKNP was caused by tourism activities and tourist waste. To resolve this issue, a policy can be applied as proposed by Dittmar [32], who stated that closing off the park to vehicular traffic and encouraging visitors to walk inside the natural environment would foster a more sustainable environment.

\section{Conclusions and Future Research}

This study concludes that the attitude of the community towards sustainable management of CKNP is generally positive; this is not only important for the local community but it also has a significant importance for the international community. The general benefits of CKNP, as identified by the local community, include: a livelihood for members of the community $(40 \%)$, tourism $(24.8 \%)$, a water supply $(15 \%)$, and a natural environment for animals and plants (12.2\%). The majority of respondents indicated that the natural environment of the park is being polluted by waste from households in the community as well as tourist activity. The general attitude of the community towards CKNP was informed by direct experience of community with the park. Government and media reporting agencies failed to attract the community's attention towards the park's declining condition. The community is afraid that pollution in CKNP will destroy the natural environment. The pollution may also negatively affect the park's socioeconomic benefits to the community. Overall, the attitude of the community towards the CKNP was found to be positive, and the community somehow showed a willingness to assume a voluntary role to conserve the park. Aside from this voluntary service, government actions towards further budget allocation for the sustainable management of CKNP were highly favored by community members. The community indicated a need to develop and manage the park, to satisfy the community's basic needs in practice and to ensure an indefinite supply of natural resources for the future. Community participation in the upkeep of CKNP will enhance interest among tourists to visit and eventually also foster community development.

This study mainly focused on a remote area of Pakistan as a target area for study, which is a unique study in natural resource sustainable management paradigm. This study may serve as a 
basis for future researchers to focus on other similarly remote areas in other developing countries. It should be added that the variables that shape community attitude towards the natural resource sustainable management of CKNP are not limited to those variables used in this study. Future studies may also include additional variables and factors to expand on those already used, so as to gain additional breadth relating to attitudes of the local community towards the sustainable management of its natural resources.

Acknowledgments: We are grateful to Peter Zelchenko M.A., [USA], Shanghai Jiao Tong University, for English-language proofreading and editing for review. We also like to thank the editors and reviewers of this issue; without their valuable input, it would not be possible to present this paper in this form.

Author Contributions: The paper was written by Talib Hussain, Jaffar Abbas, Benqian Li, Jaffar Aman and Sajjad Ali. The literature review, analysis and main idea were done by Talib Hussain, while Jaffar Abbas, Jaffar Aman and Sajjad Ali contributed to collect the data and to writing other parts of the paper. Professor Benqian Li supervised and guided the researchers to write the paper.

Conflicts of Interest: The authors declare no conflict of interest.

\section{References}

1. United Nations Statistics Division (UNSD). 2016. Standard Country or Area Codes for Statistical Use. Available online: https:/ / unstats.un.org/unsd/methodology/m49/ (accessed on 18 January 2017).

2. Central Karakoram National Park (CKNP). 2016. Available online: http://www.cknp.org/cms/ (accessed on 2 January 2017).

3. Minora, U.; Bocchiola, D.; D'Agata, C.; Maragno, D.; Mayer, C.; Lambrecht, A.; Mosconi, B.; Vuillermoz, E.; Senese, A.; Compostella, C.; et al. Glacier Changes in the Central Karakoram National Park: A Contribution to Evaluate the Magnitude and Rate of the "Karakoram Anomaly"; EGU General Assembly: Munich, Germany, 2013.

4. Junaidi, I. Pakistani Rock Climbers Can also Climb Trango Towers; Pakistan Alpine Institute: Kashmir, Pakistan, 2014.

5. Studsrod, J.E.; Wegge, P. Park people relationships: The case of damages caused by park animals around the Royal Bardia National Park. Nepal Environ. Conserv. 1995, 22, 133-142. [CrossRef]

6. Nepal, S.K.; Weber, K.E. Managing resources and resolving conflicts: National parks and local people. Int. J. Sustain. Dev. World Ecol. 1995, 2, 11-25. [CrossRef]

7. Hough, J.L. Obstacle to effective management of conflicts between national parks and surrounding human communities in developing countries. Environ. Conserv. 1997, 15, 129-135. [CrossRef]

8. Woelcke, J. Soil Mining in Eastern Uganda, Newsletter of the International Human Dimensions Programme on Global Environmental Change; IHDP: Noida, India, 2002.

9. Fabricius, C.; Koch, E.; Magome, H. Community Wildlife Management in Southern Africa: Challenging the Assumptions of Eden; International Institute for Environment and Development: London, UK, 2001.

10. Treseder, L.; Honda-McNeil, J.; Berkes, M.; Berkes, F.; Dragon, J.; Notzke, C.; Schramm, T.; Hudson, R.J. Northern Eden: Community-Based Wildlife Management in Canada, Evaluating Eden; Series No. 2. International Institute for Environment and Development: London, UK, 1999.

11. Garcia, I.; Giuliani, F.; Wiesenfeld, E. Community and sense of community: The case of an urban barrio in Caracas. J. Community Psychol. 1999, 27, 727-740. [CrossRef]

12. McMillan, D.W.; Chavis, D.M. Sense of community: A definition and theory. J. Community Psychol. 1986, 14, 6-23. [CrossRef]

13. Pailler, S.; Naidoo, R.; Burgess, N.D.; Freeman, O.E.; Fisher, B. Impacts of Community-Based Natural Resource Management on Wealth, Food Security and Child Health in Tanzania. PLoS ONE 2015, 10, 0133252. [CrossRef] [PubMed]

14. Lund, J.F. Is small beautiful? Village level taxation of natural resources in Tanzania. Public Adm. Dev. 2007, 27, 307-318. [CrossRef]

15. United Nations General Assembly (UNGA). Further initiatives for social development. In Proceedings of the Resolution (A/RES/S-24/2) adopted at the Special Session of the United Nations General Assembly, Geneva, Switzerland, 26 June-1 July 2000.

16. Dunlap, M.R. Reaching out to Children and Families: Students Model Effective Community Service; Rowman \& Littlefield: Lanham, MD, USA, 2000. 
17. Snyder, M.; Clary, E.G.; Stukas, A.A. The functional approach to volunteerism. In Why We Evaluate: Functions of Attitudes; Maio, G.R., Olson, J.M., Eds.; Lawrence Erlbaum: Hillsdale, NJ, USA, 2000; pp. 365-393.

18. Wilson, J. Volunteering. Annu. Rev. Sociol. 2000, 26, 215-240. [CrossRef]

19. McIvor, G. Sentenced to Serve: The Operation and Impact of Community Service by Offenders; Aldershot: Avebury, UK, 1992.

20. Clary, E.G.; Snyder, M. A functional analysis of altruism and prosocial behavior: The case of volunteerism. In Prosocial Behavior; Clark, M.S., Ed.; Sage: Newbury Park, CA, USA, 1991; pp. 119-148.

21. Austin, D.M.; Hasenfeld, Y. A prefatory essay on the future administration of human services. J. Appl. Behav. Sci. 1985, 21, 351-364. [CrossRef]

22. Owen, D. Opening address: Social formal and informal patterns of care. Br. J. Soc. Work 1986, 16, 5-14.

23. Sobus, M.S. Mandating community service: Psychological implications of requiring prosocial behavior. Law Psychol. Rev. 1995, 19, 153-182.

24. Zlotkowski, E. Successful Service-Learning Programs: New Models of Excellence in Higher Education; Wiley: Hoboken, NJ, USA, 1998.

25. Batson, C.D. Why act for the public good? Four answers. Personal. Soc. Psychol. Bull. (PSPB) 1994, 20, 603-610. [CrossRef]

26. Driscoll, A.; Holland, B.; Gelmon, S.; Kerrigan, S. An assessment model for service learning: Comprehensive case studies of impact on faculty, students, community, and institution. Mich. J. Community Serv. Learn. (MJCSL) 1996, 3, 66-71.

27. Griffith, R.; Mitchell, M.; Walkerden, G.; Brown, V.; Walker, B. Transformation for Resilient Landscapes and Communities, National Centre for Groundwater Research and Training Murray Catchment Management Authority NSW Natural Resources Commission; Institute for Land, Water and Society: Sydney, Australia, 2014.

28. Thakadu, O.T. Success factors in community based natural resources management in northern Botswana: Lessons from practice. Nat. Resour. Forum 2005, 29, 199-212. [CrossRef]

29. Ostrom, E.; Schroeder, L.; Wynne, S. Institutional Incentives and Sustainable Development: Infrastructure Policies in Perspective; Westview Press: Oxford, UK, 1993; Volume 266.

30. Bartley, T.; Andersson, K.; Jager, P.; Van, L. The contribution of Institutional, Theories for explaining Decentralization of Natural Resource Governance. Soc. Nat. Resour. 2008, 21, 160-174. [CrossRef]

31. Measham, T. Building capacity for environmental management: Local knowledge and rehabilitation on the Gippsland red gum plains. Aust. Geogr. 2007, 38, 145-159. [CrossRef]

32. Dittmar, H.S. The Automobile and Affording the American Dream. In Sustainable Planet: Solutions for the Twenty-First Century; Schor, J.B., Taylor, B., Eds.; Beacon Press: Boston, MA, USA, 2002; pp. 109-128.

33. Hassan, M.; Charles, H. Natural Resource and Environmental Information for Decision Making; The World Bank: Washington, DC, USA, 1992.

34. Mckenzie-Mohr, D. Fostering Sustainable Behavior: An Introduction to Community-Based Social Marketing; New Society Publishers: Gabriola Island, UK, 1999.

35. CKNP. Available online: http://www.cknp.org/cms/national-park/general-information/maps/ (accessed on 18 January 2017).

36. Cinner, J.E.; Pollnac, R.B. Poverty, Perceptions and Planning: Why Socioeconomics Matter in the Management of Mexican Reefs; Elsevier Science Ltd.: Amsterdam, The Netherlands, 2004.

37. Bohner, G.; Wanke, M. Attitudes and Attitude Change; Psychology Press, Ltd.: Hove, UK, 2002; pp. 3-242.

38. Pollnac, R.B. The Perceptions of the Coastal Environment in Indonesia. 2000. Available online: http:/ / www.crc.uri.edu/download/CM_pollnac.pdf (accessed on 8 January 2016).

(C) 2017 by the authors. Licensee MDPI, Basel, Switzerland. This article is an open access article distributed under the terms and conditions of the Creative Commons Attribution (CC BY) license (http://creativecommons.org/licenses/by/4.0/). 